Limnetica, 26 (2): 331-340 (2007). DOI: 10.23818/limn.26.28

(c) Asociación Ibérica de Limnología, Madrid. Spain. ISSN: 0213-8409

\title{
The Family Dugesiidae: New records for the Azorean Archipelago
}

\author{
Vera Malhão *, Pedro Raposeiro and Ana C. Costa \\ Universidade dos Açores, Departamento de Biologia, Rua Mãe de Deus, 58, 9500-801 Ponta Delgada, Açores, \\ Portugal \\ * Corresponding author: vmalhao@ notes.uac.pt
}

\begin{abstract}
A The Family Dugesiidae: New records for the Azorean Archipelago

The freshwater Turbellaria worms are widely distributed and live mainly in lakes, lagoons, ponds and streams. The genus Dugesia of the Family Dugesiidae, differs from another Turbellaria families in some characteristics, namely the possession of multicellular and pigmented retina eyes. These species only inhabit non polluted freshwaters systems, and therefore can be very useful as water quality indicators.

In the Azores and Madeira archipelagos, the presence of Dugesia gonocephala in Macaronesia have been previously reported (e.g. Marcus, 1959; Hughes et al., 1998) as the only member of the Family Dugesiidae family present in these islands.

New records of Dugesia for the Azores: Dugesia lugubris (Schmidt 1861) and Dugesia tigrina (Girard 1950) are reported here. The occurrence of Dugesia gonocephala and Dugesia polichroa in Azorean freshwaters is confirmed.
\end{abstract}

Key words: Dugesiidae, Azores, taxonomy, islands distribution, Macaronesia.

\section{RESUMEN}

La Familia Dugesiidae: Nuevas citas para el archipiélago de las Azores

Los Turbelarios dulceacuícolas están ampliamente distribuidos a escala global y viven principalmente en lagos, lagunas, estanques y arroyos. El género Dugesia de la Familia Dugesiidae difiere en algunas características de otras familias de Turbelarios, concretamente por la posesión de ojos con retina multicelular y pigmentada. Estas especies sólo viven en aguas dulces no contaminadas y por tanto pueden ser muy útiles como indicadores de la calidad del agua.

En los Archipiélagos de Azores y Madeira, la presencia de Dugesia gonocephala en Macaronesia ha sido previamente citada (Marcus, 1959; Hughes et al, 1998) como el único miembro de la Familia Dugesiidae presente en estas islas.

Aquí se presentan nuevas citas de Dugesia para Azores: Dugesia lugubris (Schmidt 1861) y Dugesia tigrina (Girard 1950). Se confirma la presencia de Dugesia gonocephala y Dugesia polychroa en aguas dulces de Azores.

Palabras clave: Dugesiidae, Azores, taxonomía, distribución insular, Macaronesia.

\section{INTRODUCTION}

The Azores constitute an oceanic archipelago (Fig. 1) comprising nine islands located at $36^{\circ} 55^{\prime} 43^{\prime \prime}-39^{\circ} 43^{\prime} 2^{\prime \prime} \mathrm{N}$, and $24^{\circ} 46^{\prime} 15^{\prime \prime}$ $31^{\circ} 16^{\prime} 15^{\prime \prime} \mathrm{W}, 1300 \mathrm{~km}$ apart from the nearest European continental coast and $1900 \mathrm{~km}$ from the American Continent. The islands lie in three groups: an eastern group consisting of Santa Ma- ria and São Miguel, a central group of five islands: Terceira, Graciosa, São Jorge, Pico, and Faial, and a western one formed by Flores and Corvo islands (Green, 1992). All these islands have a relatively recent volcanic origin, ranging from 8 to 12 Myr B.P. (Santa Maria) to 300.000 years B.P (Pico) (Nunes, 1999). The temperate oceanic climate is characterised by high levels of atmospheric humidity that can reach $95 \%$ in 


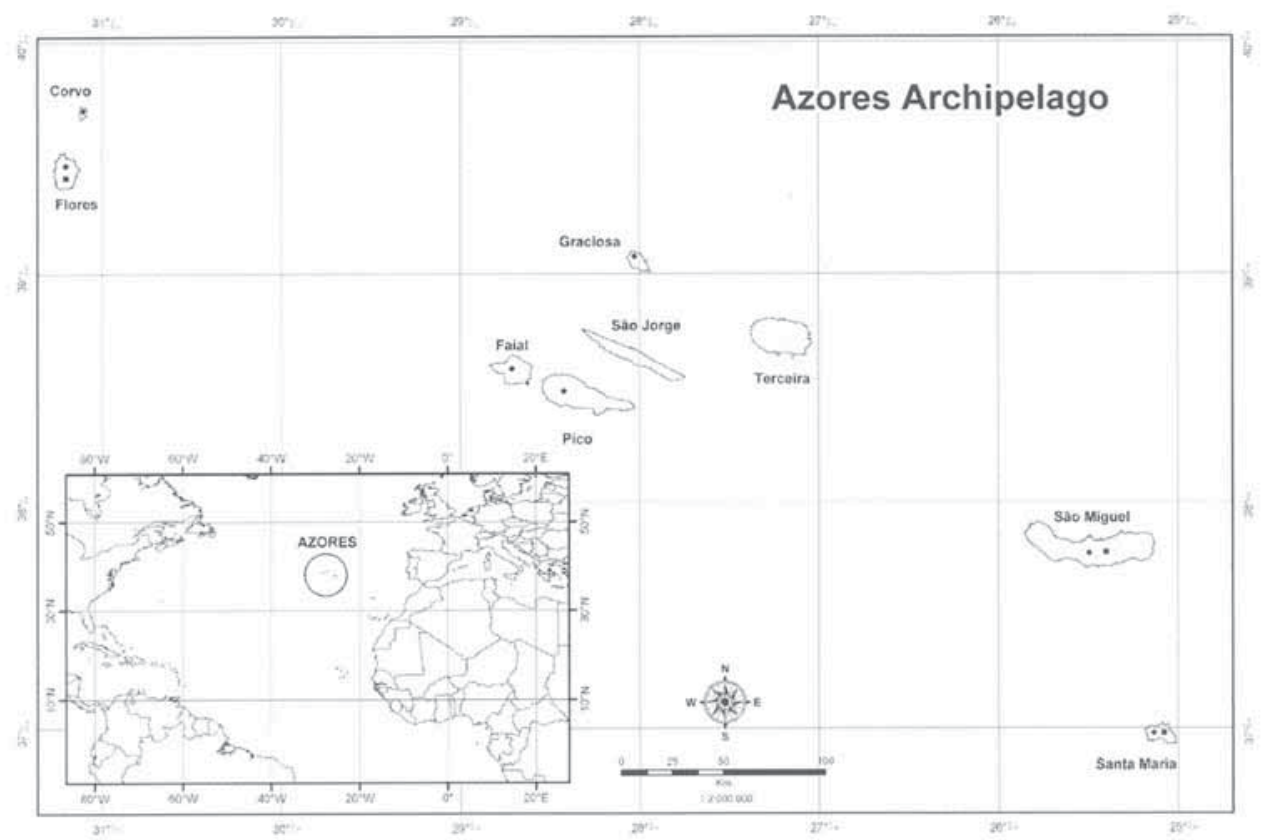

Figure 1. Azores archipelago Islands sampled; $\square$ islands where Dugesiidae specimens were found. Archipiélago de las Azores; - islas muestreadas; $\mathbf{a}$ islas donde se encontraron especímenes de Dugesiidae.

high altitude native forests and ensures little thermal variation throughout the year (Borges et al. 2005). Being the most remote archipelago in the North Atlantic (Fig. 1), the Azores together with Madeira, Canary Islands, and Cabo Verde form the biogeographic region known as Macaronesia.

Triclad flatworms, commonly known as planarians, constitute a monophyletic suborder within the Platyhelminthes. Freshwater triclads or planarians are fragile animals that do not possess resistant stages against desiccation or temperature extremes. They depend on the aquatic environment during their whole life cycle, and have very low resistance to salinity. Flatworms do not possess a larval stage (Vries, 1985) and biochore dispersal seems to be insignificant, being bad dispersers, distributed mainly through contiguous freshwater bodies (Ball, 1974). Therefore, the historical geological events in the area under study have to be taken into account to explain the present distribution of triclads.

The freshwater triclad genus Dugesia, of the family Dugesiidae Ball, 1974, has been subjected to major phylogenetic studies (Ball, 1974). The
Dugesiidae family is very widespread occurring mainly in lakes, usually in shallow water on sheltered stony shores due to their photonegative sensitivity (Reynoldson \& Young, 2000).

Dugesiidae are flattened, elongated worms that simultaneously display predatory and scavenger strategies (Reynoldson \& Young, 2000). The head is triangular, possessing or not lateral auricles, usually with two eyes, rarely four as in D. polychora. Body surface is usually pigmented displaying a uniform grey or brown or mottled colour pattern (Garcia, 1987). These flatworms are hermaphrodite that can reproduce asexually by fission, in which the animal splits in half and then regenerates the missing body parts (Ruppert et al., 2004). Sexual reproduction is also possible and results in a few eggs laid in a cocoon (Reynoldson \& Young, 2000).

Dugesia (Dugesia) gonocephala sensu lato is a superspecies, which comprises numerous closely related species differing from each other in their morphology (Benazzi, 1955).

In his work "Sur la faune des Eux Douces des Açores" in 1896, Barrois refers the presence 
of Dugesia polychroa and Dugesia sp. at São Miguel Island. Marcus (1959), in his work about freshwater Turbellaria of the Azores, mentions the presence of the Dugesiidae family present in São Miguel, Santa Maria, and Flores islands. Hughes et al. (1998), in their checklist of the freshwater macroinvertebrates from Madeira, elaborated upon literature surveys and a museum collection, reported that Dugesia gonocephala is present in all archipelagos of Macaronesia.

The objectives of the present work were to identify and report the freshwater planarians collected during a freshwater invertebrates' inventory, contributing in this way to the assessment of the freshwater biodiversity of the archipelago.

\section{MATERIAL AND METHODS}

Six out of nine islands from the Azorean archipelago were sampled: São Miguel, Santa Maria, Flores, Corvo, Graciosa, and Pico (Fig. 1). The number of sites sampled for each island was: 27 in Flores, 4 in Corvo, 4 in Pico, 1 in Faial, 42 in São Miguel, and 10 in Santa Maria. The worms were collected in Flores island between October 2004 and February 2006, in São Miguel between February 2005 and June 2006, and Santa Maria from September 2005 to June 2006.

A large number of habitats were prospected at each sampling station (lentic and lotic zones, streams, river banks, floating vegetation, etc.) to assess the biological diversity at the site. With the same purpose, some emerged stones were explored at the site and the worms found there were collected with a brush. After collection, worms were usually preserved in $96 \%$ ethyl alcohol.

The specimens were identified (in vivo) whenever possible at laboratory with the support of the identification key of Garcia (1987) based on detailed observation under a dissecting microscope and measured when necessary using a calibrated scale with the eyepiece of the microscope. The animals were preserved in $70 \%$ ethyl alcohol. All the animals are deposited in the Zoology Laboratory of the University of the Azores.

\section{RESULTS}

\section{Systematic account-Description of the collected species}

Suborder Tricladida Lang, 1884

Infraorder Paluldicola Hallez, 1892

FAMILIY DUGESIIDAE BALL, 1974

Dugesia gonocephala (Dugès, 1830)

Dugesia gonocephala is a common and widespread freshwater triclad species in the Old World (Vries \& Ball, 1980). This species is considered a superspecies, comprising a number of a closely related species resembling each other in external appearance, but differing in internal anatomy and aspects of their kariology (Benazzi, 1955). The taxonomy within this group has proved to be complicated (Vries, 1984). Living animals are up to $18 \mathrm{~mm}$ long and $3 \mathrm{~mm}$ wide (Vries, 1984). Head is low triangular shaped with two eyes, each consisting of a multicellular pigment cup containing many retinal cells; the colour of the dorsal surface is usually some shade of grey or brown, the pigment varying in intensity; the ventral surface is somewhat paler than the dorsal surface and with marginally placed auricular streaks just behind the eyes, which are free of pigment (Vries, 1984).

\section{Dugesia lugubris (Schmidt 1861)}

This species is widespread in Europe and usually occurs in the same habitats as Dugesia polychroa (Reynoldson \& Young, 2000). D. lugubris is characterized for having two eyes separated by an inter-ocular distance larger than the length between the anterior border of the head and the eyes. Its colour is dark brown to black in the dorsal surface and paler in the ventral surface (Garcia, 1987). It reproduces sexually, producing stalked cocoons like its congener D. polychroa (Reynoldson \& Young, 2000). Living animals measure between 20 to $30 \mathrm{~mm}$ (García, 1987).

Dugesia tigrina (Girard, 1950)

D. tigrina is native to North America where it is widespread in several habitats (Reynoldson \& 
Table 1. List of the collected species: D. lugubris $\square$; D. gonocephala $\square$; D. polychroa $\bullet$; D. tigrina $\bigcirc$; at the studied sites (SStream; L-Lake) of the Eastern Group Azorean archipelago, sampled between February of 2005 and September of 2006. Island of occurrence, altitude, temperature, $\mathrm{pH}$, conductivity and number of individuals captured (ni) are presented. Lista de las especíes colectadas: D. lugubris $\square$; D. gonocephala $\square$; D. polychroa $\bullet$; D. tigrina $\bigcirc$; en los lugares estudiados (S-Río; L-Lago) del Grupo Occidental del Archipiélago de los Azores, muestreados entre Febrero de 2005 y Setiembre de 2006, isla en que se ha encontrado, altitud, temperatura, $\mathrm{pH}$, conductividad e número de individuos (ni).

\begin{tabular}{|c|c|c|c|c|c|c|c|c|}
\hline Island & Site & Type & Altitude (m) & Sampling date & Temperature $\left({ }^{\circ} \mathbf{C}\right)$ & $\mathrm{pH}$ & Conductivity $(\mathrm{S} / \mathrm{cm})$ & Species \\
\hline \multirow{34}{*}{ São Miguel } & \multirow{6}{*}{ Salto da Inglesa } & \multirow{6}{*}{ S } & \multirow{6}{*}{280} & Fev-05 & - & - & - & $\overline{\square(6)}$ \\
\hline & & & & Fev-05 & - & - & - & $\overline{\square(2)}$ \\
\hline & & & & Mai-05 & - & - & - & $\boldsymbol{\square}(47) / \square(3) / \bullet(1)$ \\
\hline & & & & Set-05 & 20,6 & 8,88 & 19,6 & $\mathbf{\square}(9)$ \\
\hline & & & & Fev-06 & - & - & - & $\mathbf{\square ( 2 )}$ \\
\hline & & & & Set-06 & 19,9 & 9,04 & 20,5 & $\boldsymbol{\square}(2) / \bullet(2)$ \\
\hline & \multirow{3}{*}{ A. Fogo 1} & \multirow{3}{*}{ S } & \multirow{3}{*}{574} & Mai-05 & - & - & - & $\mathbf{\square ( 3 )}$ \\
\hline & & & & Mar-06 & 13,0 & 7,31 & 8,6 & - (1) / $\square(1)$ \\
\hline & & & & Mai-06 & - & - & - & $\square(2)$ \\
\hline & A. Fogo 2 & $\mathrm{~S}$ & 574 & Fev-05 & 10,9 & 7,30 & 4,2 & $\overline{\mathbf{E}(5)}$ \\
\hline & Congro & $\mathrm{L}$ & 420 & Fev-05 & 13,1 & 7,30 & 9,1 & $\overline{\mathbf{D}(4)}$ \\
\hline & \multirow{2}{*}{ Empadadas Sul } & \multirow{2}{*}{$\mathrm{L}$} & \multirow{2}{*}{750} & Fev-05 & 9,0 & 7,10 & 4,4 & - (13) \\
\hline & & & & Set-06 & 18,8 & 8,28 & 2,8 & - (37) \\
\hline & \multirow{3}{*}{ Furnas } & \multirow{3}{*}{$\mathrm{L}$} & \multirow{3}{*}{280} & Fev-05 & 13,0 & 7,80 & 13,0 & $\overline{\mathbf{D}}(8)$ \\
\hline & & & & Mai-05 & 17,3 & 8,60 & 12,3 & $\mathbf{\square ( 3 ) / \square ( 1 )}$ \\
\hline & & & & Jun-06 & - & - & - & $\boldsymbol{\square ( 2 ) / \square ( 1 )}$ \\
\hline & Fogo & $\mathrm{L}$ & 574 & Mar-06 & - & - & - & 口 (4) \\
\hline & \multirow{2}{*}{ R. Caldeirões } & \multirow{2}{*}{ S } & 80 & \multirow{2}{*}{ Abr-05 } & 13,5 & 7,80 & 10,6 & $\overline{\mathbf{\square}(1)}$ \\
\hline & & & 34 & & 13,8 & 7,90 & 12,3 & $\overline{\square(2)}$ \\
\hline & & & & Abr-05 & 13,0 & 7,70 & 13,8 & $\overline{\square(1)}$ \\
\hline & R. Faial Terra & S & 360 & Mai-06 & 14,2 & 7,45 & 9,4 & $\square(2) / \bullet(2) / \square(1)$ \\
\hline & \multirow{2}{*}{ R. Guilherme } & \multirow{2}{*}{$S$} & 261 & \multirow{2}{*}{ Abr-05 } & 12,8 & 7,70 & 9,0 & $\overline{\mathbf{\square}(1)}$ \\
\hline & & & 11 & & 14,4 & 7,70 & 9,2 & $\overline{\mathbf{\square}(3)}$ \\
\hline & R. da Praia & $\mathrm{S}$ & 450 & Mai-06 & 15,5 & 7,30 & 6,8 & $\overline{\mathbf{D}(4)}$ \\
\hline & R. Povoação & $S$ & 18 & Jun-06 & 16,1 & 7,40 & 17,1 & $\square(13) / \square(4)$ \\
\hline & \multirow{3}{*}{ R. Quente } & $S$ & 232 & Abr-05 & 13,3 & 7,70 & 18,5 & $\boldsymbol{\square ( 2 ) / \square ( 1 )}$ \\
\hline & & \multirow[b]{2}{*}{ S } & \multirow[b]{2}{*}{186} & Abr-05 & 14,8 & 7,00 & 16,5 & $\boldsymbol{\square}(6)$ \\
\hline & & & & Jun-06 & 16,8 & 6,54 & 15,3 & $\boldsymbol{\square ( 9 3 ) / \square ( 2 )}$ \\
\hline & R. Teixeira & $\mathrm{S}$ & 174 & Mai-06 & 17,4 & 7,25 & 30,4 & $\overline{\mathbf{D}(2)}$ \\
\hline & \multirow{5}{*}{ Sete Cidades } & \multirow{5}{*}{$\mathrm{L}$} & \multirow{5}{*}{260} & Fev-05 & 12,5 & 7,90 & 8,8 & $\overline{\square(9)}$ \\
\hline & & & & Mai-05 & 17,4 & 8,70 & 9,1 & $\overline{\square(5)}$ \\
\hline & & & & Set-05 & 23,3 & 9,48 & 11,9 & $\overline{\square(2)}$ \\
\hline & & & & Jun-06 & 18,6 & 7,00 & 8,6 & $\mathbf{\square}(1)$ \\
\hline & & & & Set-06 & 23,3 & 8,18 & 9,3 & $\mathbf{\square ( 5 )}$ \\
\hline & R. Santa Barbara & $S$ & 255 & Jun-06 & 17,4 & 7,51 & 20,0 & $\overline{\square(2)}$ \\
\hline & & & & Set-05 & 21,2 & 8,40 & 36,7 & $\overline{\mathbf{\square}(2)}$ \\
\hline Santa Maria & R. S. Francisco & S & 97 & Jun-06 & 16,4 & 7,34 & 18,1 & $\square(18) / \square(4)$ \\
\hline & & & 198 & Jun-06 & 16,2 & 7,40 & 17,5 & $\bar{\nabla}(6)$ \\
\hline
\end{tabular}


Young, 2000). D. tigrina reproduces usually by fission, but a sexually reproducing population has been studied in detail (Gee et al., 1998). It is characterized by the presence of two eyes; its coloration is uniformly brownish with some blotches, some dark longitudinal branches and the pharynx is pigmented (Garcia, 1987).

\section{Dugesia polychroa (Schmidt 1861)}

This species is widely distributed in Europe (Dahm \& Gourbault, 1978) and it has been introduced to and become established in North America (Boddington \& Mettrick, 1974). This worm may be found in the quiet reaches of streams and rivers (Reynoldson \& Young, 2000). Dugesia polychroa is an iteroparous triclad, breeding sexually within the range of 10 to $23^{\circ} \mathrm{C}$. The genus as a whole is more characteristic of warmer climates but $D$. polychroa and D. lugubris can tolerate hard winters (Reynoldson, 2000).

\section{Characteristics of the collected species}

The Dugesia worms found during the sampling months had the average size, shape, and coloration reported in the literature. The data is presented in abundance (total number of individuals-ni) and relative frequency ( $\%$ ).

Dugesia sp. was found in three of the six sampled islands: Santa Maria, São Miguel, and Flores. The species D. lugubris and D. tigrina were found for the first time in Azores.

As can be seen in Table 1 Dugesia lugubris was found at São Miguel island, Santa Maria island, and at Flores island (Table 2). Flores was the island where the most worms of this specie were collected, with a total of 322 individuals (96\%), while São Miguel island scored second in D. lugubris abundance with a total of 260 $(79 \%)$ animals captured and in Santa Maria island just only $28(87 \%)$ worms of this species were sampled (Fig. 2).

Dugesia tigrina seems to exist only in São Miguel Island (Fig. 2). It was found in great numbers (50 worms; $15 \%$ ) at Empadadas lake in close relation with macrophytes. In A. Fogo, a stream flowing into Fogo Lake only one specimen was captured (Table 1).
Dugesia gonocephala was also found at São Miguel, Santa Maria, and Flores islands. In São

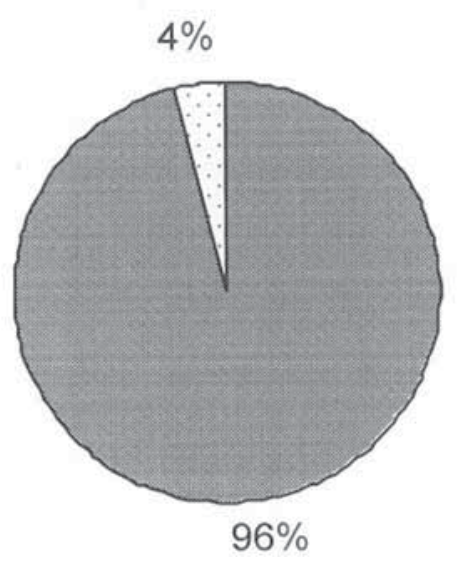

a)

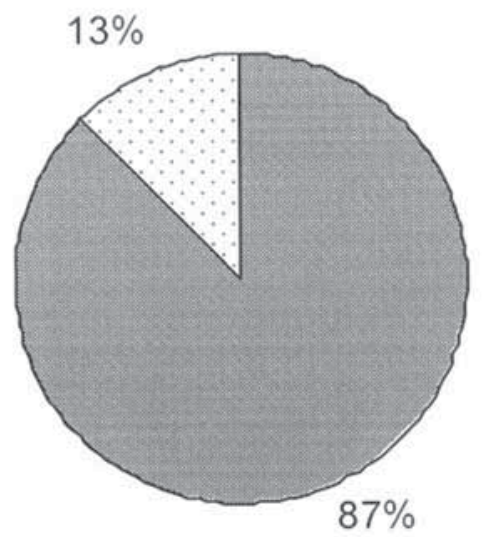

b)

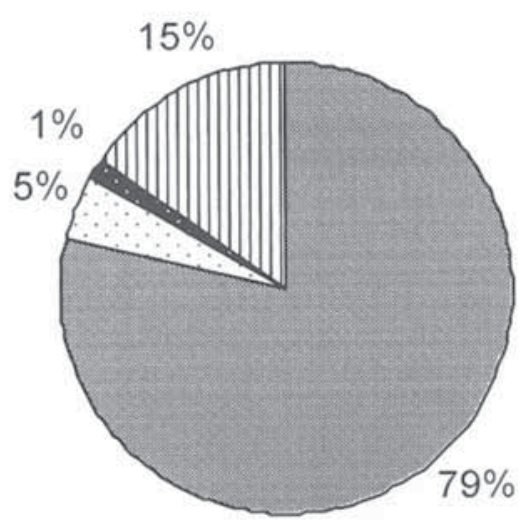

c)

Figure 2. Frequency of Dugesiidae species in the islands a. Flores b. Santa Maria c. São Miguel (图 D. lugubris; $D$. gonocephala; $\square$ D. polychroa $;$ 向 D. tigrina). Frecuencia de especímenes de Dugesiidae en las islas a. Flores b. Santa Maria

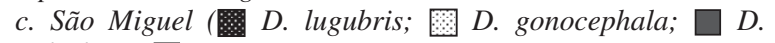
polychroa; $\mathbb{W}$ D. tigrina). 
Miguel (Table 1) this species was only collected in Furnas Lake and in five streams (Salto da Inglesa, A. Fogo, Faial da Terra, Povoação, and Quente) with a total of 16 specimens (5\%) (Fig. 2). In Flores island the abundance of $D$. gonocephala was very similar to São Miguel, since 13 worms $(4 \%)$ were captured there. $D$. gonocephala also inhabits lakes and streams, but seem to prefer the latter. The lake sampled at Flores island was Lomba Lake and the streams

Table 2. List of the collected species: D. lugubris $\square$; D. gonocephala $\square$; D. polychroa $\bullet$; D. tigrina $\bigcirc$; at the studied sites (SStream; L-Lake) of the Western Group of Azorean archipelago, sampled between October 2004 and April of 2006, Island of occurrence, altitude, temperature, $\mathrm{pH}$, conductivity and number of individuals captured (ni) are presented. (Source of physicalchemical parameters: INOVA: Instituto de Inovação Tecnologica dos Açores). Lista de las especíes colectadas: D. lugubris $\mathbf{\square}$; D. gonocephala $\square$; D. polychroa $\bullet$; D. tigrina $\bigcirc$; en los lugares estudiados (S-Río; L-Lago) del Grupo Oriental del Archipiélago de los Azores, mиestreados entre Octubre de 2004 y Abril de 2006, isla en que se ha encontrado, altitud, temperatura, pH, conductividad e número de individuos (ni). (Fuente de los parámetros fisico-químicos: INOVA: Instituto de Inovação Tecnologica dos Açores).

\begin{tabular}{|c|c|c|c|c|c|c|c|c|}
\hline Island & Site & Type & Altitude (m) & Sampling date & Temperature $\left({ }^{\circ} \mathbf{C}\right)$ & $\mathrm{pH}$ & Conductivity (S/cm) & Species \\
\hline & & & & Out-04 & 13,0 & 4,40 & - & $\boldsymbol{\square}(4)$ \\
\hline & A. Comprida & $\mathrm{S}$ & 550 & Abr- 05 & 10,7 & 6,71 & - & $\mathbf{\square}(4)$ \\
\hline & & & & Fev-06 & 11,2 & 7,50 & 3,3 & $\overline{\square(3)}$ \\
\hline & & & & Out-04 & 12,1 & - & - & $\boldsymbol{\square}(9)$ \\
\hline & & & & Jan-05 & 13,7 & 8,33 & - & $\mathbf{\square ( 7 )}$ \\
\hline & A. Funda 2 & $S$ & 365 & Abr-05 & - & - & - & $\boldsymbol{\square}(33)$ \\
\hline & & & & Set-05 & 20,4 & 11,74 & 10,9 & $\boldsymbol{\square ( 7 )}$ \\
\hline & & & & Fev-06 & 14,1 & 7,73 & 12,1 & $\boldsymbol{\square}(2) / \square(1)$ \\
\hline & & & & Out-04 & 12,8 & 7,34 & - & $\mathbf{\square ( 5 )}$ \\
\hline & 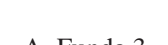 & $\mathrm{S}$ & 260 & Jan-05 & - & - & - & $\boldsymbol{\square}(9)$ \\
\hline & A. Funda 3 & $\mathrm{~S}$ & 301 & Set-05 & 18,1 & 7,93 & 12,3 & $\boldsymbol{\square}(11)$ \\
\hline & & & & Fev-06 & 14,4 & 7,36 & 12,0 & $\mathbf{\square}(1) / \square(2)$ \\
\hline & Comprida & $\mathrm{L}$ & 570 & Out-04 & 15,2 & 5,60 & - & $\overline{\square(1)}$ \\
\hline \multirow[t]{17}{*}{ Flores } & Lomba & $\mathrm{L}$ & 650 & Out-04 & 14,9 & 7,00 & 5,8 & $\square(1)$ \\
\hline & \multirow{2}{*}{ Rasa } & \multirow{2}{*}{$\mathrm{L}$} & \multirow{2}{*}{530} & Out-04 & 15,5 & 6,00 & 6,7 & $\boldsymbol{\square ( 3 )}$ \\
\hline & & & & Jan-05 & 13,8 & 6,10 & 6,2 & $\boldsymbol{\square}(11)$ \\
\hline & R. Badanela & S & 10 & Set-05 & 20,5 & 8,27 & 15,2 & $\mathbf{\square}(8) / \square(1)$ \\
\hline & R. Cruz & $\mathrm{S}$ & 140 & Abr- 05 & - & - & - & $\boldsymbol{\square}(3) / \square(1)$ \\
\hline & \multirow{4}{*}{ R. Fazenda } & \multirow{4}{*}{ S } & \multirow{2}{*}{300} & Jan-05 & 12,4 & 7,10 & 13,1 & $\boldsymbol{\square ( 2 2 )}$ \\
\hline & & & & Set-05 & 18,2 & 7,15 & 9,6 & $\boldsymbol{\square ( 1 3 )}$ \\
\hline & & & \multirow{2}{*}{14} & Jan-05 & 14,3 & 7,50 & 23,2 & $\mathbf{D ( 7 9 )}$ \\
\hline & & & & Set-05 & 21,0 & 7,58 & 23,2 & $\boldsymbol{\square}(7)$ \\
\hline & \multirow{8}{*}{ R. Grande } & \multirow{8}{*}{ S } & \multirow{3}{*}{557} & Jan-05 & 11,0 & 6,20 & 5,0 & $\boldsymbol{\square}(1)$ \\
\hline & & & & Out-05 & 18,0 & 6,08 & 0,0 & $\overline{\square(8)}$ \\
\hline & & & & Abr-06 & 16,0 & 7,80 & 14,4 & $\square(2)$ \\
\hline & & & \multirow{3}{*}{198} & Jan-05 & 12,6 & 7,50 & 11,1 & 口(4) \\
\hline & & & & Set-05 & 17,9 & 8,10 & 14,3 & $\mathbf{\square ( 1 7 )}$ \\
\hline & & & & Abr-06 & 15,0 & 7,87 & 11,4 & $\square(1)$ \\
\hline & & & \multirow{2}{*}{11} & Jan-05 & 13,9 & 7,80 & 13,3 & $\boldsymbol{\square ( 3 )}$ \\
\hline & & & & Set-05 & 19,1 & 8,41 & 16,8 & $\mathbf{\square}(47) / \square(4)$ \\
\hline
\end{tabular}


were A. Funda, Badanela, Cruz, and Grande (Table 2). In Santa Maria only 4 worms were captured in S. Francisco stream, being this the one with the lower abundance when compared to the other islands (Table 1)

Dugesia polychroa capured is restricted to two streams (Salto da Inglesa and Faial da Terra) in São Miguel (Table 2) island, where a total of 4 animals (1\%) were captured (Fig. 2). However, in 1896 some organisms were captured at Serra Gorda, Fonte of Vila Franca, and Dr. Caetano d'Andrade Park, as well as between the villages of Furnas and Povoação.

\section{DISCUSSION}

This study contributes to a better knowledge of the biodiversity of the Azores, as three new species were found for the first time in this archipelago: Dugesia lugubris and Dugesia tigrina representing new records for Macaronesia as well.

Dugesiidae was not evenly distributed in the archipelago. In Pico, Graciosa, Corvo and Faial islands no Dugesiidae specimens were found (Fig. 2). Unexpectedly, regarding the previous records of $D$. gonocephala, $D$. lugubris is more widespread than $D$. gonocephla not only for Macaronesia in general but also inside the Azorean archipelago like in Santa Maria, São Miguel, and Flores islands. Dugesia gonocephala is widespread in Europe, Africa and Asia (Sluys \& Jong, 1984). The other Dugesia species' here reported are distributed in Europe; Dugesia lugubris mainly observed in the southern and north-eastern margins of the Mediterranean, D. polychroa is abundant in Iberian Peninsula (Vries, 1985), and D. tigrina, native from North America, was introduced in Europe, Japan (Reynoldson \& Young, 2000), and in several parts of the world by human activities (Gee et al., 1998). Reynoldson and Young (2000) claimed that colonisation of productive lakes containing a large number of triclad species by Dugesia tigrina, can result in the decimation of the native species'. That might be the case in Empadadas Lake in São Miguel, as all captured worms were D. tigrina, which might have taken the habitat by displacement of other flatworm species' or otherwise prevented the establishment of other direct competitor.

Taking into account the generalist distribution of the Dugesiidae family, including its occurrence in the Mediterranean (Charni et al., 2004) its presence in Azores is not surprising. However, a better knowledge on the distribution of this family in the archipelago would need a better spatial sampling coverage of the region and an increase in sampling efforts. It is not surprising that the largest island, São Miguel would be the one where all of the four species were found, due to the general rule of area-species of island biogeography, where the number of species on a given island is usually related to the area of the island (MacArthur \& Wilson, 2001). São Miguel was also the island where a stronger sampling effort was done and therefore, a better sampling coverage of habitat and sampling points was possible, resulting in a better and more intensive sampling that might be reflected in the results. These might be the reasons for the high abundance and diversity in this island. Second in flatworms abundance was Flores Island whose small size, location, and distance to the closest island might prevent the existence of a more diverse tricladid fauna. This island presented less Dugesia species' and the same was true for Santa Maria. However, in the latter just one locality was sampled thus limiting the probability of finding other Dugesia species, besides $D$. lugubris. Some of the reasons why no flatworms were found in some sites could be the unsuitability of substrates for colonisation by $\mathrm{Du}$ gesia spp. justifying the absence of Dugesia in Pico and Corvo Islands. In fact. in lakes Dugesia spp. need sheltered, stony shores (Reynoldson \& Young, 2000), and in Corvo Island the substrata is very smooth and composed by sand and clay. In Pico there are no stony shores and the presence of Odonata species', which prey on tricladida, is very strong. In Graciosa Island, the absence of the genus Dugesia can be justified by the marked seasonal character of the ponds that are the only freshwater systems in the island.

It seems that sampling effort might have influenced the results, so an increase in sampling 
sites in all islands of the archipelago is very advisable to confirm the diversity and abundance of this family in the Azores.

The detailed observation of the morphology of the specimens was enough for species' identification, but histological studies are now being carried out to confirm the identifications with anatomical traits.

\section{ACKNOWLEDGEMENTS}

This work was partially supported by Direcção Regional dos Recursos Hídricos of the Azores Government. We thank Dr. Ronald Sluys for all his support namely providing access to literature and in the identification of some specimens. We also want to thank Dr. David Santos for the revision of the Spanish abstract. Special thanks are due to Iolanda Silva for her English language revision.

\section{REFERENCES}

AZEVEDO, J. M. N., V. GONÇALVES, P. RAPOSEIRO, A. I. COUTO \& A. C. COSTA. 2005. Contribuição para o conhecimento biológico das águas interiores da Graciosa. XI Expedição Cienífica do Departamento de Biologia Graciosa 2005. Relatórios e comunicações do Departamento de Biologia, 32: 143-150.

BALL, I. R. 1974. A contribution to the Phylogeny and Biogeography of the freshwater triclads (Platyhelminthes: Turbellaria). In: Biology of the Turbellaria. N.W. Riser \& M.P. Morse (eds.): 339401. New York: Mc Graw-Hill.

BARROIS, TH. 1987. Recherches sur la faune des eux douces des Açores. Memoires de la Société des Sciences, de l'Agriculture et des Arts de Lille (5 serie), fas. 6: 1-272.

BENAZZI, M. 1955. Evoluzioni della poliploidia nella planarie appartenenti alla superspecie Dugesia gonocephala. Atti Accad. Naz. Lincei. (8) 18: $527-$ 533.

BODDINGTON, M. J. \& D. F. METTRICK. 1974. The distribution, abundance, feeding habitas and population biology of the immigrant triclad Dugesia polychora (Platyhelminthes: turbellaria) in Toronto Harbour, Canada. J. Anim. Ecol. 43: 681-699.
BORGES, P. A. V., C. AGUIAR, A. AMARAL, I. R. AMORIM, G. ANDRÉ, A. ARRAIOL, A. BAZ, F. DINIS, H. ENGHOFF, C. GASPAR, F. ILHARCO, V. MAHNERT, C. MELO, F. PEREIRA, J. A. QUARTAU, S. P. RIBEIRO, J. RIBES, A. R. M. SERRANO, A. B. SOUSA, R. Z. STARUSSEN, L. VIEIRA, V. VIEIRA, A. VITORINO \& D. J. WUNDERLICH. 2005. Ranking protected areas in the Azores using standardised sampling of soil epigean arthropods. Biodiversity and Conservation, 14: 2029-2060.

CHARNI, M., A. H. H. HARRATH, R. SLUYS, S. TEKAYA \& F. ZGHAL. 2004. The freshwater planarian Dugesia sicula lepori, 1948 (Platyhelmintes, Tricladida) in Tunisia: ecology, kariology, and morphology. Hydrobiologia, 517: 161-170.

DAHM, A. G., \& N. GOURBAULT. 1978. Tricladida et temnocephalida (Turbellaria). In: Limnofauna Europea.. J. Illies (ed.): 16-20. Stuttgart and New York. Gustav Fischer.

GARCÍA, J. G. 1987. Claves de identificación de los turbelarios de las aguas continentales de la Península Ibérica e Islas Baleares. Asociacion Española de Limnologia. Publicaciones de la Universitat de Barcelona. 34 pp.

GEE, H., J. R. PICKAVANCE \& J. O. YOUNG. 1998. A comparative study of the population of the American immigrant triclad Dugesia tigrina (Girard) in two British lakes. Hydrobiologia, 361: 135-143.

GOMES, A., J. L. GASPAR \& G. QUEIROZ. 2006. Seismic vulnerability of dwelling at Sete Cidades Volcano (S. Miguel Island, Azores). Natural Hazards and Earth Sciences System Sciences, 6: 41-48.

GREEN, J. 1992. Island biogeography, diversity and dominance of zooplankton in crater lakes on the Azores. Biological Journal of the Linnean Society, 46: 189-205.

HUGHES, S. J., FURSE, M. T., BLACKBURN, J. H. \& P. LANGTON. 1998. A checklist of Madeiran Freshwater Macroinvertebrates. Bol. Mus. Mun. Funchal., 50(284): 5-41.

MACARTHUR, R. \& E. WILSON. 2001. The theory of Island Biogeography. Princeton: Princeton University Press. 203 pp.

MARCUS, E. \& E. MARCUS. 1959. Turbellaria from Madeira and the Azores. Bol. Mus. Mun. Funchal, 12 (30): 14-42.

NUNES, J. C. C. 1999. A actividade vulcânica na ilha do Pico do Plistocénio superior ao Holocénio: 
mecanismo eruptivo e Hazard vulcânico. 3 volumes. Tese de Doutoramento, Universidade dos Açores, Angra do Heroísmo. Portugal.

REYNOLDSON, T. B. \& J. O. YOUNG. 2000. A key to the Freshwater Triclads of Britain and Ireland with Notes on their Ecology. Cumbria: Freshwater Biological Association. 25 pp.

RUPPERT, E. E., R. S. FOX \& R. B. BARNES. 2004. Platyhelminthes, Orthonectidae, and Dicyemida. In: Invertebrates Zoology. $7^{\text {th }}$ edition. (10): 225-266. Brooks Cole. Belmont, USA.

SLUYS,R. \& H. DE JONG. 1984. Chromosome Morphological Studies of Dugesia gonocepha- la. S. L. (Platyhelminthes, tricladida). Caryologia, 37: 9-20.

VRIES, E. J. \& I. R. BALL. 1980. On Dugesia gonocephala from Western Europe. Bijdragen tot de Dierkunde, 50 (2): 342-340.

VRIES, E. J. 1984. On the species of the Dugesia gonocephala group (Platyhelmintes, Turbellaria, Tricladida) from Greece. Bijdragen tot de Dierkunde, 54 (1): 101-126.

VRIES, E. J. 1985. The biogeography of the genus Dugesia (Platyhelmintes, Turbellaria, Paludicola) in the Mediterranean region. Journal of Biogeography, 12: 509-518. 